\title{
OFF TARGET: PROFESSOR AHIAKPOR ON KEYNES, MILL, AND SAY'S LAW
}

BY

\author{
ROY H. GRIEVE
}

The purpose of my paper on "Keynes, Mill, and Say's Law" is to demonstrate that John Stuart (J. S.) Mill (1866), despite denying the validity of the "identity" interpretation of Say's Law, was, contrary to the views of certain recent commentators, quite properly characterized by John Maynard Keynes (1936, p. 18) as holding by the proposition that "in some significant, but not clearly defined, sense ... the whole of the costs of production must necessarily be spent in the aggregate, directly or indirectly, in purchasing the product." James Ahiakpor (JA) also accepts that Mill took a classical position on Say's Law. It is therefore somewhat unexpected that he devotes his critical note (Ahiakpor, present volume, hereinafter 2018) to dismissing, as a muddle of misrepresentation and misunderstanding, my efforts to illuminate the (surprisingly questioned) fact of Mill's basic adherence to the Say's Law doctrine. Mill, although not subscribing to "Say's Identity," was no early anticipator of Keynes. I reckon that JA, in offering a slew of confused and confusing comments, has completely failed to grasp what I am getting at in the paper in question. Let us (insofar as space permits) review a few of my alleged misunderstandings and misrepresentations.

We begin with what JA describes as "Grieve's most fundamental misrepresentation of Mill's restatement of the law of markets" - "his claim that Mill envisaged investment as the purchase of wage goods only" (Ahiakpor 2018, p. 268). Actually, I said nothing of the sort; furthermore, the matter is trivial. I merely pointed out that Mill, while of course fully aware of the employment of fixed capital in production, did sometimes write as if the provision of working capital (such as wage-goods) was all that was required to "put labour into motion." For instance, in describing the supposed consequences of increased saving by the wealthy when population happens to be increasing, Mill argues that employment can be maintained if the new savings are put to the production of additional "capital"- by which he means "production of necessaries for the new population" (Mill 1866, I, v, 3, p. 42). The fact that on occasion Mill appears to represent "capital" simply by reference to working capital is of no importance: what is important, but overlooked by JS, is Mill's characteristic presumption that under (normal, non-crisis) conditions, income saved is automatically put into the production of capital goods.

Roy H. Grieve, University of Strathclyde, Glasgow. (Retired.)

ISSN 1053-8372 print; ISSN 1469-9656 online/18/02000275-278 @ The History of Economics Society, 2018 doi:10.1017/S1053837217000451 
Such is implied by Mill's "extreme cases" (Mill 1866, I, v, 3, pp. 42-43; and III, xiv, 3, p. 339), that if the wealthy cut out all their luxury consumption, the resultant savings will not go to waste but will instead undoubtedly be invested in labor for producing wage-goods. Why, we might ask, should it be supposed that labor released from luxury production will thus automatically be redeployed? JA, however, completely misunderstanding the issue, responds with the observation that "Grieve is unable to conclude that a reduction in demand for luxuries by capitalists and landlords would reduce their prices, reduce their profitability, and cause a reduction of their production. He also could not anticipate that the increased relative profitability of wage-goods production would motivate their increased production" (2018, p. 268). JA has altogether missed the point: Mill was not attempting to describe the consequences merely of a shift of consumers' preference from good A to good B, but asserting that with the abandonment of luxury expenditures, and new saving, an equal volume of investment spending must necessarily emerge.

Mill is incorrect in arguing that, in the circumstances envisaged, workers' expenditure can be relied upon to make up for effective demand lost through the new frugality of the propertied classes. He is confident that no problem can arise. What is the basis of that confidence? Variously, he seems to rely on the unemployed workers' finding employment, but, with the wealthy having cut their spending to the bone, how can it be profitable to employ them? He does hint at a fortuitous increase in population, but, failing that, his alternative solution is apparently a redistributive transfer to the existing workforce of the surplus purchasing power of the wealthy (how is that to be achieved?). My contention is that Mill is here revealing a confused readiness to assert that, with respect to demand for output, it doesn't matter however much savings are made out of income, we can take it for granted that these savings will, somehow, be balanced by an equal volume of alternative spending.

Another ill-founded allegation made by JA is that "Grieve also fails to interpret correctly the fund meaning of capital Mill employs in his "fourth fundamental theorem", (2018, p. 271). That notorious fourth proposition states that it is not expected demand for output, but the prior accumulation of a fund of resources for supporting labor in employment that determines the quantity of labor demanded by employers. I take the position that while it is perfectly possible to understand this theorem, the problem with it is that it makes no sense: realistically, the specific nature and quantity of what is to be manufactured by labor must be known before capital can be accumulated to support that labor in production. JA makes the mystifying comment that "Kates's not clarifying the proposition in terms of the wages fund may have hindered Grieve's understanding" (2018, p. 272).But, of course, it is the wages-fund theory itself to which I am objecting!

Again, according to JA, "Grieve compounds his misrepresentation of Mill's analysis by attributing to him the belief that 'full recovery from a commercial crisis is automatic and quick"'(2018, p. 269). Mill is quite clear about this: he is not referring, as JA may be supposing, to recovery from a slump situation such as envisaged by the heretics (Robert Malthus, Thomas Chalmers, and Jean Charles Léonard de Sismondi), but to the kind of short, sharp crisis the features of which he described in detail. By a "commercial crisis," Mill meant a financial panic. Normal commercial activity breaks down due to the collapse of businessmen's mutual trust in the solvency of those with whom they do business. A desperate demand for cash in hand and temporary withdrawal from market 
activity results. Such crisis conditions Mill did indeed regard as self-correcting and transient. As he put it, " $[\mathrm{I}] \mathrm{t}$ is true that this state can only be temporary, and must even be succeeded by a reaction of corresponding violence, since those who have sold will certainly buy at last, and there will then be more buyers than sellers" (Mill [1844] 1874, Essay II, para. 73). ${ }^{1}$

Consider another of JA's objections: “Grieve appears not to have understood Mill's explanation that all the money ... is always held by income earners and producers. Rather, Grieve recognizes the existence of money's demand (to hold) only during periods of commercial crisis" (2018, p. 270). That is nonsense. JA has apparently not understood that J. S. Mill-unlike his father and Jean-Baptiste Say-perceived the emergence, in conditions of commercial crisis, of an abnormally intense desire to hold money. In my paper I draw attention to that recognition and its implication that J. S. Mill accepted that on occasion agents did indeed prefer to hang on to money rather than spend it on goods and services. I make the point that although in this respect J. S. Mill's understanding was superior to the theory of his mentors, that in itself was not enough to justify his characterization, by some recent commentators (see Grieve 2016), as some sort of quasi-Keynesian. Mill held to the belief that, crisis conditions aside, supply generates demand, not vice versa.

Yet a further charge: "Grieve further misrepresents Mill as having limited only to commercial crisis "investment [being] subject to risk and uncertainty"' (2018, p. 269). Again: "Grieve repeats Keynes's misrepresentation of the proponents of Say's Law, including Mill, of not being cognizant of uncertainty in the expectation of entrepreneurs' profits" (ibid., p. 269). In suggesting that Mill gave insufficient attention to "risk and uncertainty" in the context of the investment decision, what I had in mind was Mill's apparent misuse of David Ricardo's theory of profits (not mentioned by JA). Ricardo's proposition is that, given the physical productivity of the economic system, the rate of profit established depends only on the division of net output between capital and labor. Mill (1866, II, xv, 6, p. 252) draws from Ricardo the mistaken conclusion that "the general profit of the country is always what the productive power of labour makes it, whether any exchange takes place or not," adding, "whatever prices may or may not be." But for the transformation of a potential physical surplus into a value surplus-which is of course what the capitalist is seeking - the investor must take account of particular market conditions, of current and prospective prices, of what may be known and of what may be highly uncertain. It very much looks as if Mill too readily put to the side the difficulties facing investors in a world of uncertainty when attempting to value prospective investment returns. There is no indication that, beyond the chaos of a financial crisis, Mill envisaged investors holding back from committing funds because of doubts as to the outcome.

This rebuttal of JA's charges could be continued, and JA's reading of Mill further questioned, but we have run out of space. I conclude that none of the points raised by JA add to our understanding of Mill on the subject of Say's Law.

\footnotetext{
${ }^{1}$ Note further: "It is also evident that this temporary derangements of markets is an evil only because it is temporary" (Mill 1866, III, xiv, 4, p. 340).
} 


\section{REFERENCES}

Ahiakpor, James C. W. 2018. “Keynes, Mill and Say’s Law: A Comment on Roy Grieve’s Mistaken Criticisms of Mill." Journal of the History of Economic Thought 40(2): 267-273.

Grieve, Roy H. 2016. "Keynes, Mill and Say's Law: The Legitimate Case Keynes Didn't Make against J. S. Mill.” Journal of the History of Economic Thought 38 (3): 329-349.

Kates, Steven. 2015. “Mill's Fourth Fundamental Proposition on Capital: A Paradox Explained.” Journal of the History of Economic Thought 37 (1): 39-56.

Keynes, John Maynard. 1936. The General Theory of Employment, Interest and Money. London: Macmillan.

Mill, John Stuart. [1844] 1874. Essays on Some Unsettled Questions of Political Economy. London: Longmans, Green Reader, and Dyer.

1866. Principles of Political Economy. Eighth edition. London: Longmans, Green, Reader, and Dyer. 